ORIGINAL ARTICLE

\title{
Correlation between Serum Ferritin and C-reactive protein levels in Dialysis Naïve Chronic Kidney Disease Patients in a Nigerian Tertiary Hospital
}

${ }^{1}$ Makusidi AM, ${ }^{1}$ Chijioke A, ${ }^{3}$ Biliaminu SA, ${ }^{2}$ Shittu AO, ${ }^{2}$ Sanni MA, ${ }^{3}$ Abdul-Rahman MB, ${ }^{3}$ Abdul-Azeez IM

Departments of 1Medicine, 2Haematology and 3Chemical Pathology, University of Ilorin Teaching Hospital, Ilorin, Nigeria.

Correspondence: Dr AM Makusidi,

UDUTH,PMB 2370, Sokoto,Nigeria.

E-Mail: makusidi1@yahoo.com

\begin{abstract}
Background: Serum ferritin level is one of the iron indices recommended for assessing iron deficiency and overload. Iron deficiency is a major contributory factor to anaemia and lack of response to erythropoietin therapy in Chronic Kidney Disease (CKD). Serum ferritin is often elevated in CKD because of chronic inflammatory process of which raised $\mathrm{C}$-reactive protein is a surrogate marker. It is for these reasons that we undertook this study in a bid to determine any correlation between serum ferritin and C-reactive proteins among CKD patients.

Objectives: To determine any relationship between serum ferritin and C-reactive proteins among our CKD patients.

Methods: This was a descriptive cross - sectional study that was conducted over a 6month period (April to October 2010). Patients that met the criteria for CKD were recruited from nephrology clinic of University of Hlorin Teaching Hospital, Nigeria, while healthy staff members from the same hospital served as controls. Blood samples collected from patients and controls were used to determine serum ferritin level, complete blood count, C-reactive protein, urea, creatinine, total protein and albumin, by standard procedures. Data obtained was analyzed using SPSS version 16.

Results: One hundred and twenty patients and 60 healthy subjects were studied. The mean serum ferritin level of patients and controls were $194 \pm 162.99$ and $28.77 \pm 10.49$ respectively. Ferritin level increased with worsening of renal function. Mean and range of C-reactive protein (CRP) of patients were 237.94 \pm 173.96 and 18-743, while $162.27 \pm 133.18$ and 6-437 were control values. There was poor correlation between serum ferritin and $\mathrm{C}$ - reactive protein. The mean haemoglobin concentration of the patients was $9.3 \pm 2.6$ with mean PCV of $29.4 \pm 8.4$. Ninety six $(82 \%)$ patients had haemoglobin concentration $<11 \mathrm{~g} / \mathrm{dl}$.

Conclusion: Anaemia is very common in the presence of elevated or normal ferritin level and worsening renal function among our CKD patients. There was poor correlation between serum ferritin and C-reactive proteins. An aggressive iron replacement therapy before considering the use of erythropoietin in our anaemic CKD patients may be rewarding.
\end{abstract}

Keywords: Ferritin, C-reactive protein, Anaemia, CKD, Ilorin

\section{INTRODUCTION}

The National Kidney Foundation and Kidney Disease Outcomes Quality Initiative (NKF$\mathrm{K} / \mathrm{DOQI}$ ) practice guidelines recommend maintaining ferritin above $100 \mathrm{ng} / \mathrm{ml}$ to ensure adequate iron supply for erythropoiesis among patients with chronic kidney disease (CKD), irrespective of whether or not they are dependent on dialysis ${ }^{1}$. Accurate assessment of iron status is a prerequisite for diagnosing its deficiency, monitoring response to erythropoietin therapy and maintenance of effective erythropoiesis. ${ }^{2,3}$ Serum ferritin level is one of the iron indices for assessing iron deficiency and overload ${ }^{4}$. Inaccurate information on serum ferritin level can lead to false interpretation, resulting in unnecessary discontinuation or overdose of iron, as iron deficiency is a major contributory factor to lack of response to erythropoietin therapy in chronic kidney disease. ${ }^{5,6}$ Cardiovascular event is a leading cause of death in CKD in developed countries and is fast becoming major health issue in developing nations ${ }^{7}$. An early treatment of anaemia in CKD is 
recommended since reduced haemoglobin values are associated with left ventricular hypertrophy, increased frequency and duration of hospitalization and reduction in the quality of life. ${ }^{8,9}$ Serum ferritin is often elevated in CKD because of the associated chronic inflammatory process of which raised Creactive protein is a surrogate marker.

Information on serum ferritin levels and its correlation with C-reactive proteins will form a basis for rational iron therapy in anaemia of CKD. There is paucity of such studies in our environment. It is for these reasons that we undertook this study in a bid to determine any relationship between serum ferritin and Creactive proteins among our $\mathrm{CKD}$ patients.

\section{SUBJECTS AND METHODS}

This was a descriptive cross - sectional study that was conducted over a 6- month period (April to October 2010). Patients that met the criteria for stages 1 to $4 \mathrm{CKD}^{10}$ were consecutively recruited from the nephrology clinic, while healthy staff members of University of Ilorin Teaching Hospital community served as controls. The study received approval from the Ethical and Research Committee of the hospital and written consent was obtained from study subjects. Information obtained from study subjects include demographic data, blood pressure, weight, height, waist circumference, hip circumference, body mass index and waist/hip ratio. The cause of CKD, duration of illness and co-morbid conditions were also documented. For the purpose of this study, anaemia was defined as packed cell volume $<$ $33 \%$ or haemoglobin concentration $<11 \mathrm{gm} / \mathrm{dl}$, normal ferritin level was between $300 \mathrm{ng} / \mathrm{ml}$ and $500 \mathrm{ng} / \mathrm{ml}$, ferritin deficiency as < $300 \mathrm{ng} / \mathrm{ml}$ and absolute ferritin deficiency as $<100 \mathrm{ng} / \mathrm{ml}$. Patients were on dietary regimen and fluid therapy devoid of iron supplement for at least 4 weeks prior to the study. Excluded from the study were patients that received blood transfusion in the preceding three months, stage $5 \mathrm{CKD}$, very ill patients requiring urgent dialysis and those with haematological disorders.

$10 \mathrm{mls}$ of venous blood was collected from each patient and control without stasis. The blood was subsequently divided into haematology and biochemistry bottles for analysis with specific reference to serum ferritin level, complete blood count, C reactive protein, urea, creatinine, total protein and albumin levels. Serum ferritin was measured, using MicroWell ${ }^{\mathrm{TM}}$ Ferritin Enzyme Immunoassay system for the quantitative determination of ferritin in human serum (Batch no \#2610-96, Syntron Bioresearch, Inc.). ${ }^{11}$ The blood for haematological parameters, using standard procedure ${ }^{12}$ was collected and anticoagulated in EDTA. The blood for measurement of plasma creatinine by Jaffe method in our routine laboratory was anticoagulated in lithium heparin.

Data obtained from the study was analyzed using SPSS version 16. The absolute figures and means \pm standard deviation (SD) of parameters measured were stated, while relationship between variables and ferritin levels were determined using multiple regression analysis. $\mathrm{P}$ value $<0.05$ was considered significant.

\section{RESULTS}

One hundred and twenty patients (63 males, 57 females) were studied while 60 healthy subjects (32 males, 28 females) served as controls. The overall mean age of patients was $41.6 \pm 16.1$ with a range of $15-70$ years, while male and female mean ages were $42.6 \pm 17$ and $40.4 \pm 15$ years with a range of $17-70$ years and 15-67years respectively. Mean body mass index for males and females were $21.8 \pm 2.8$ and $22.5 \pm 7.2$ respectively.

The mean serum ferritin level of patients and controls were $194 \pm 162.99$ and $28.77 \pm 10.49$ respectively and the difference was statistically significant $(\mathrm{p}<0.01)$.

Mean and range of C-reactive protein (CRP) of patient were $237.94 \pm 173.96$ and $18-743$, while $162.27 \pm 133.18$ and $6-437$ were control values. 
The difference in mean CRP values of these patients and controls was statistically significant $(\mathrm{p}<0.01)$ and there was weak positive correlation between ferritin and CRP levels in patients and controls $(\mathrm{r}=0.214, \mathrm{p}=$ 0.06). The results (Table I) showed that $23 \%$ had normal ferritin, while $36 \%$ and $48 \%$ had ferritin deficiency and absolute ferritin deficiency respectively as defined by $\mathrm{NKF} / \mathrm{KDOQI}$. Overall, $78 \%$ of these patients were deficient in ferritin and there were no cases with ferritin overload. Surprisingly all the controls were also deficient in ferritin as depicted in Table I below.

Table I: Serum Ferritin levels in subjects with CKD and Controls

\begin{tabular}{lcc}
\hline \multicolumn{1}{c}{ Iron in ng/ml } & No. of Pts $(\%)$ & No. of Control $(\%)$ \\
\hline$>500$ & - & - \\
$300-500$ & $27(22.5 \%)$ & - \\
$101.99-299.99$ & $43(35.8)$ & $15(25)$ \\
$\leq 100$ & $50(41.7)$ & $45(75)$ \\
\hline Total & $120(100)$ & $60(100)$
\end{tabular}

The mean $\mathrm{Hb}$ and $\mathrm{PCV}$ of controls were $13.1 \pm$ 1.4 and $40.1 \pm 4.4$ respectively. Table II depicts the stratification of ferritin levels in relation to CKD classification. It shows progressive increase in ferritin level that varied directly with severity of renal disease.

Table II: Stratification of Ferritin level in relation to CKDClassification
The range and mean of haemoglobin concentration and mean corpuscular volume (MCV) of patients were 3.6 - 15.2 with mean of $9.3 \pm 2.6$ and 67-92 and mean volume of $78.96 \pm 6.4$ respectively (Table III).

Table III: Haematological and Biochemical Parameter s ofCKD patients.

\begin{tabular}{lll}
\hline Parameters & Range & Mean \pm SD \\
$\mathrm{Hb}$ & $3.6-15.2$ & $9.3 \pm 2.6$ \\
$\mathrm{MCV}$ & $67-92$ & $78.96 \pm 6.4$ \\
$\mathrm{MCH}$ & $20-30$ & $25.3 \pm 2.2$ \\
$\mathrm{CRP}$ & $5.9-743$ & $236.6 \pm 175.5$ \\
\hline Caicium & $2-3.9$ & $2.9 \pm 0.45$ \\
Albumin & $32-62$ & $43.2 \pm 7.0$ \\
& & \\
Ferritin & $30-500$ & $194.0 \pm 162.88$
\end{tabular}

The difference in haematocrit value between patients and control was statistically significant $(\mathrm{p}<0.01)$. Anemia $(\mathrm{Hb}<11 \mathrm{gm} / \mathrm{dl})$ was present in $82 \%$ of the patients and the severity of anaemia varied directly with the loss of renal function. The serum ferritin levels correlated positively with age, $\mathrm{Hb}$ and $\mathrm{MCV}$ $(\mathrm{p}<0.036, \mathrm{p}<0.01, \mathrm{p}<0.01)$, but there was

\begin{tabular}{lcccccc}
\hline \multicolumn{4}{l}{ Stage of CKD No of Patients (\%) Mean Age } & Mean eGFR & \multicolumn{3}{l}{ Mean Ferritin level “r” } & p-value \\
\hline I & $13(10.8)$ & $42 \pm 14.7$ & $117.8 \pm 9.3$ & $158.8 \pm 82.3$ & 0.567 & 0.143 \\
II & $22(18.3)$ & $41.8 \pm 21.2$ & $74.4 \pm 10.8$ & $194 \pm 160.5$ & -0.586 & 0.045 \\
III & $57(47.5)$ & $40.3 \pm 15.4$ & $43.8 \pm 8.3$ & $237.3 \pm 174.1$ & 0.202 & 0.224 \\
IV & $28(23.3)$ & $40.1 \pm 15.4$ & $22.0 \pm 3.9$ & $156.5 \pm 174.3$ & -0.270 & 0.311 \\
V & - & - & - & - & - & - \\
\hline G/Total & $\mathbf{1 2 0 ( 1 0 0 )}$ & $\mathbf{4 1 . 3 4}$ & $\mathbf{5 2 . 3 6}$ & $\mathbf{2 0 2 . 4 7}$ & $\mathbf{- 0 . 0 4 6} \mathbf{0 . 6 9 2}$ \\
\hline
\end{tabular}


weak correlation with $\mathrm{C}$-reactive proteins and no correlation with BMI $(\mathrm{p}>0.05)$.

\section{DISCUSSION}

Iron deficiency is the most common cause of resistance to erythropoietin therapy in CKD, contributing to ineffective erythropoiesis and haematocrit values below the recommended target of $11 \mathrm{gm}$ per deciliter. ${ }^{13}$ It is speculated that many patients in late stages of CKD may have impaired iron utilization rather than frank iron deficiency. Serum ferritin level is one of the iron indices for assessing iron deficiency and overload. Accurate determination of iron status is made difficult by the presence of chronic inflammation and co-morbid conditions that affect commonly used indices for iron stores. ${ }^{14}$ Chronic inflammation in association with malnutrition and infections increases the risk of misdiagnosing ferritin overload which may lead to iron deficiency from inappropriate withdrawal of iron therapy. ${ }^{14}$ The finding of ferritin deficiency of varying severity in $78 \%$ of our patients is in agreement with the observation of other workers $^{15-17}$. Studies in dialysis patients in United State of America revealed that more than $60 \%$ were deficient in iron based on serum ferritin level of less than $100 \mathrm{ng} / \mathrm{ml}$.

Many factors have been implicated in the genesis of iron deficiency of CKD. These include accelerated erythropoiesis from erythropoietin therapy, blood losses from dialyzers and tubings, blood sampling, needle placement, needle removal and gastro intestinal route. ${ }^{16,17}$ The high cost of erythropoietin therapy renders optimizing iron status necessary as enormous cost would result from wide spread and aggressive use of erythropoietin in a population that is deficient in iron. The fore knowledge of ferritin level as surrogate marker of iron status will aid decision as to when to initiate iron therapy in CKD. Although, it may be possible to improve anaemia in CKD with high dose of erythropoietin, but prior correction of identified iron deficiency can achieve the same result with lower doses of erythropoietin ${ }^{1}$. Iron deficiency is the most common factor for erythropoietin resistant anaemia in predialysis CKD patients and the consequences include decreased cognitive function, decreased exercise tolerance and increased left ventricular hypertrophy. ${ }^{16}$ There is also evidence that correction of anaemia may help in slowing the decline in renal function in CKD. ${ }^{18}$ An early detection and correction of iron responsive anaemia may prevent and/or cause regression of left ventricular hypertrophy $(\mathrm{LVH})$ which is a strong predictor of sudden death in CKD patients. ${ }^{19-21}$

Positive correlation between serum ferritin and haemoglobin levels, accord with may indicate that the severity of iron deficiency is an important factor in the pathogenesis of anaemia of CKD. ${ }^{5,6,8,17,22,23}$ Of importance in this study is the observation that majority of control subjects had low serum ferritin levels. The disparity in serum ferritin among CKD patients and control is not clear. It may be related to iron balance which is significantly altered in chronic kidney disease because of the associated chronic inflammation that stimulates cytokine release that result in elevation of hepcidin levels. An increased hepatic hepcidin production which prevents gastrointestinal iron absorption and release of iron from reticuloendothelial system is the likely mechanism blocking effective iron utilization in anaemia of $\mathrm{CKD}^{24}$. The increase in serum ferritin during inflammation may hinder the ability to assess iron status in $\mathrm{CKD}^{25}$. Thus the use of arbitrary upper limit of $500 \mathrm{ng} / \mathrm{ml}$ as criteria for withholding iron therapy in CKD may be flawed because moderately elevated ferritin do not necessarily connote iron overload. ${ }^{26}$

Our findings support the notion that advanced CKD patients suffer from generalized inflammation which lead to blockage of iron utilization. ${ }^{27}$ This implies that ferritin levels are likely to be elevated in CKD which will alter the diagnostic properties of ferritin levels in the assessment of iron status. The observation of marked elevation of C-reactive proteins (CRP) among patients in contrast to controls is in agreement with presence of chronic inflammatory process. ${ }^{28}$ Since there was poor correlation between C-reactive proteins and serum ferritin in our study, the observation of elevated C-reactive protein is likely due to associated chronic inflammation. Chronic inflammation is common in CKD patients and 
up to $40-70 \%$ of patients may have persistent increase in C-reactive proteins. ${ }^{29}$ It appears from this study that our anaemic CKD patients will need iron supplement before and during erythropoietin therapy in order to improve cost - effectiveness of epoietin. In patients with CKD, hyperferritinemia is paradoxically associated with more severe anaemia ${ }^{30}$. The institution of iron therapy prior to erythropoietin is strongly advocated in resource poor nations in view of the high cost of erythropoietin.

Left ventricular hypertrophy in CKD is due to increased cardiac output, driven by anaemia induced peripheral vasodilatation and LVH is associated with 2.9 fold increase in mortality from ESRD. ${ }^{31}$ The maintenance of target haematocrit of $12 \mathrm{gm} / \mathrm{dl}$ has been shown from previous series to decrease hospitalization and improve quality of life. ${ }^{32-35}$

The serum ferritin findings in our study need to be interpreted with caution as transferrin saturation and newer tests like reticulocyte haemoglobin content, percentage of hypochromic red cells and soluble transferrin receptor studies were not done. ${ }^{36}$ Transferrin saturation usually deals with circulating iron rather than storage iron and iron status is more indicative of iron overload. The decision on upper limit of serum ferritin at which iron therapy should be withheld requires careful balancing between potential benefits and risks to patients. ${ }^{37}$

In conclusion, anaemia is very common in the presence of elevated or normal ferritin level and worsening renal function among our CKD patients. There was poor correlation between serum ferritin and C-reactive proteins. The marked elevation of C-reactive protein levels in these patients supports poor iron utilization related to chronic inflammation. An aggressive iron replacement therapy before considering the use of erythropoietin in our anaemic CKD patients may be rewarding. A more comprehensive and multicenter assessment of iron status in CKD patients with and without erythropoietin therapy is advocated.

\section{REFERENCES}

1. National Kidney Foundation: NKF
-K/DOQI Clinical practice Guideline for Anaemia of Chronic Kidney Disease: Update 2000 . A m. J . Kid. Dis.2001;37(suppl):S182-S284

2. Horl WH, Cavill I, Macdongall IC, Schaefer RM, Sunder-Plasmonu G. How to diagnose and correct iron deficiency during erythropoietin therapy - a consensus report. Nephrol - Dial Transplant. 1996; 11:246-250.

3. Enders HM. Evaluating iron status in haemodialysis patients. Nephrol. Nurs. J. 2002; 29: 366-370.

4. K/DOQI Clinical practice guidelines and clinical practice recommendations for anaemia in chronic kidney disease in adults. Am. J. Kid Dis. 2006; 47 (suppl); S11-S145.

5. McClellan W, Aronoff SL, Botton WK, Hood S, Lobber DL et al. The prevalence of anaemia in patients with chronic kidney disease. Curr. Med. Res. Opin. 2004; 20:1501-1510.

6. Horl WH, MacDougall IC, Roster J, Schaefer RM. OPTA-therapy with iron and erythropoietin stimulating agent in chronic kidney disease. Nephrol-Dial-Transplant. 2007; 22 (suppl); iii2-ii6.

7. Levey AS, Beto JA, Coronado BE, Eknoyan G, Foley. RN, Kasiske BL, Wag MJ, Mailloux LU, Manske CL, Meyer KB et al. Controlling the epidemic of cardiovascular disease in chronic kidney disease. What do we know? National Kidney foundation task force on cardiovascular disease. Am. J. Kid Dis. 1998; 32: 853-906.

8. Horl WH. Clinical aspects of iron use in the anaemia of chronic kidney disease $\mathrm{J}$. Am. Soc. Nephrol. 2007; 18:383-393.

9. Vychytil A, Haag-Weber M. Iron status and iron supplementation in peritoneal dialysis patients. Kid Intern. 1999; 69 (suppl): S71-S78.

10. Levey AS, Eckardt KU, Tsukamotoo Y, 
Levin A, Coresh J, Rossert J, De Zeeuw D, Hostetter TH, Lameire N, Eknoyan G. Definition and classification of chronic kidney disease: A position statement from kidney disease: Improving Global outcome (KDIGO). Kid. Intern. 2005; 67:2089-2090.

11. Cook JD, Finch CA, Smith NJ. Evaluation of iron status of a population. Blood, 1976; 48: 449-455.

12. Bain BJ. Basic haematological techniques. In: Practical haematology: edition eds Dacie JV and Lewis SM. Chil-chil Livingstone, Edinburgh. 1993; 49-97.

13. Hudson JQ, Comstock TJ. Consideration for optimal iron use for anaemia due to chronic kidney disease. Clin. Ther. 2001; 23: 1637-1671.

14. Coyne D. Iron indices: what do they really mean: Kid intern. 2006 ; 101 (suppl): S4S8.

15. UNITED STATES RENAL DATA SYSTE. USRDS 1996. Annual data report 1996. Bethesda, National institute of health, National institute of diabetes and digestive and kidney disease.

16. Nissenson AR, Strobes J. Iron deficiency in patients with renal failure. Kid intern. 1999; 55 (suppl): S18-S21.

17. HSU Chi-yuan, Mcculoch CE, Curhan GC. Iron status and haemoglobin level in chronic renal insufficiency. J. Am. Soc. Nephrol. 20002; 1:2783-2786.

18. Nauman Tarif. Anaemia management in patients with chronic renal disease: current recommendations. Saudi J. Kid dis. And Transpl. 2002; 13:331-335.

19. Levin A, Singer J, Thompson CR, Rose H, Lewis M. Prevalent left ventricular hypertrophy in the predialysis population: identifying opportunities for intervention. Am. J. Kid Dis. 1996; 27:347-354.

20. Bedani PL, Verzola A, Bergama M,
Stabellini g, Gilli P. Erythropoietin and cardiocirculatory condition in aged patient with chronic renal failure. Nephron 2001; 89: 350-353.

21. Levin A, Thompson CR, Ethier J. Left ventricular mass index increase in early renal disease; impact of decline in haemoglobin. Am. J. Kid. Dis 1999; 34: 125-134.

22. Silverberg DS, Blum M, Agbaria Z, Deutsch V, Irony M, Schwartz D, Baruch R. et al, Intravenous iron supplement for the treatment of anaemia of moderate to severe chronic renal failure patients not on dialysis. Am J. Kid. Dis. 1996; 27: 234238.

23. Silverberg. DS, Blum M, Agbaria Z, Deutsch V, Irony M, Schwartz D. et al. The effect of intravenous iron alone or in combination with low dose erythropoietin in the rapid correction of anaemia of chronic renal failure in the predialysis period. Clin. Nephrol. 2001; 55: 212-29.

24. Ganz T. hepcidin: A key regulator of iron metabolism and mediator of anaemia of inflammation. Blood 2003; 102: 783-788.

25. Sakiewicz P, Paranimi E. The use of iron in patients with chronic dialysis: Mistakes and misconceptions. J. Nephrol. 1998; $11: 5-15$.

26. Yamanishi H, Iyama S, Yamaguchi Y, Kanakura Y, Twatani Y. Relation between iron content of serum ferritin and clinical status factors extracted by factor analysis in patients with hyperferritinemia. Clin. Biochem. 2002; 35:523-529.

27. Kaysen GA, The micro inflammatory state in uremia: causes and potential consequences. J. Am. Soc. Nephrol. 2001, 12: $1549-1557$.

28. Levin A, Finger J, Thompson CR. Prevalent left ventricular hypertrophy and systolic dysfunction in chronic renal failure. Am. J. Kid Dis. 1996; 27-357-354.

29. Kalanter - Zadehi K, Don BR, Rodiguez 
RA, Humphrey MH. Serum ferritin level is a marker of morbidity and mortality in haemodialysis patients. Am. J. Kid. Dis. 2001;37:564-572.

30. Kirchbaum B. Profiling haemodialysis patients with high serum ferritin levels. Clin. Nephrol. 2001;56:117-123.

31. Silberberg JS, Barre PE, Pritchard SS, Sniderman AD. Impact of LVH on survival in ESRD. Kid Intern. 1989; 36: 286-290.

32. Collins AJ, Li S, Peter W, Ebben J, Roberts $\mathrm{T}$, Jennie Z, Manning W. Death, Hospitalization and Economic association among incident haemodialysis patients with haematocrit value of 36 to $39 \%$. J. Am. Soc. Nephrol. 2001; 12:2465-2473.

33. McMahan LP, McKenna MJ, Sangkabutra T, Mason K, Sostaric S, Skinner SL, Burge C, Murphy B, Crankshaw D. Physical performance and associated electrolytic change after haemoglobin normalization: a comparative study in haemodialysis patients. Nephrol - dial- Transpl. 1999; 14:1782-1187.

34. Pickett JL, Theberge DC, Brown WS Schweitzer SU, Nissenson AR. Normalizing haematocrit in dialysis patients improves brain function. Am. J. Kid dis. 1999; 33:112-130.

35. Benz RL, Pressman MR, Horick EJ, Peterson DD. A preliminary study on the effects of correction of anaemia with epoietin therapy on sleep, sleep disorder and day time sleepiness in haemodialysis patients (SLEEP study). Am. J. kid Dis. 1999; 34:1093-1094.

36. Wish JB. Assessing Iron Status: Beyond Serum Ferritin and Transferrin Saturation. Clin. J.Am. Soc. Nephrol.2006;1:S4-S8

37. Fishbane S, Kalantar - Zadeh K, Nissenson AR. Serum ferritin in CKD: Reconsidering the upper limit of iron treatment. Semin. Dial. 2004;17:330-341 